\title{
Trade Liberalization in Textiles and Clothing: A Comparative Analysis of Policy Responses between Indonesia and Bangladesh 2010-2015
}

\author{
${ }^{1}$ Irhamna, ${ }^{2}$ Riaty Raffiudin \\ ${ }_{1}^{1}$ Master Program in Political Science \\ Department of Political Science, Universitas Indonesia \\ Senior Lecturer and Researcher \\ ${ }^{2}$ Department of Political Science, Universitas Indonesia \\ Depok, 16424, Indonesia \\ Email:irhamna51@ui.ac.id/irhamna.irham@gmail.com
}

\begin{abstract}
Thisarticle examines the policy responses from the government of Indonesia and Bangladesh to address the impact of liberalization in textiles and clothing towards women workers from 2010 to 2015. Using the gendered political economy perspective by Wedderburn \& Jackson (2008) and Mengesha (2008), this article is aimed to answer the research question:How the two countries deliver their policy responses to overcome the impact of trade liberalization in textiles and clothing on women workers between 2010-2015? This study used a qualitative method with secondary data. The findings of this study suggest that the two countries reacted differently to address the impact of trade liberalization. The Indonesian governmenttends to response the changes byempowering the women workers through Government Regulation No.78 Year 2015 on Remuneration. On the other hand, The Bangladesh government tends to respond the changes by expanding their industries using the Export Processing Zones (EPZs).
\end{abstract}

Keywords: policy responses, trade liberalization, textiles, clothing, women workers.

\section{GENDERED POLITICAL ECONOMY PERSPECTIVES ON TRADE LIBERALIZATION IN TEXTILES AND CLOTHING}

The international trade regime on textiles and clothing (T\&C) has been significantly changed since the Agreement on Textiles, and Clothing (ATC) was ended in late 2004. The new era had just begun in 2005, the liberalization of T\&C under the protocol of General Agreements on Tariffs and Trade (GATT), continued to a single undertaking regime maintained by World Trade Organization (WTO). Liberalization as its prolific feature was aimed to open the market, expand the demand, and gained the economics of scale. Trade liberalization will be shrinking the production cost, promoting competition and triggered innovations. In the end, through several channels trade liberalization has some impacts on economic growth (Stiglitz \& Charlton, 2005).

Since the Washington Consensus been implemented, liberalization, openness, growth, and elimination of poverty became the main argument of global political economy. The political economy context of liberalization will trigger the redistribution. Sally (2009) argued there be five factors that determined trade policy reform in a country: economic condition, interest, idea, institution, and endowments (Sally, Alves, \& Draper, 2009).

The agreement on trade liberalization in T\&C can be traced back to 1994 when the Uruguay Round was held. The changing into themore liberal system had made the developing countries unable to gain the revenue compared when thequotawas still imposed. Indonesia for instance, by the time trade liberalization, was started in 2005, there was a significant reduction in $\mathrm{T} \& \mathrm{C}$ production, from $4 \mathrm{~kg} /$ capita to 3,5 $\mathrm{kg}$ /capita (Hermawan, 2011). Heron (2012) argued that Uruguay Round be a grand bargain between the developed countries and developing countries. Agreement on Textile and Clothing (ATC) as the successor of Multifiber Arrangement (MFA) can be seen differently. Unlike the MFA that tends to benefit the developed countries, ATC is tried to accommodate the developing countries' interests. The negotiation of themultilateral agreement shall involve all the stakeholders, including the developing countries. Their participation in the negotiation could be crucial concerning their interest and position. There are three main arguments on why developing countries shall be participated: (1) the outcomes of international negotiation are not pre-determined by the relative power of 
countries, developing countries can affect the outcomes; (2) developing countries will have replicable lessons, particularly on potential role of inter-country alliances; (3) providing information and analysis on a more systematic basis on how international negotiations might affect national interests, can improve the quality of participation and negotiate success (Page, 2002).

The implementation of ATC has become a new challenge for thedomestic market. They are required to formulate a new strategy to deal with quota, given the dependency to imported textile materials (Heron, 2012). Single undertaking trade regime under WTO was aimed to make global economic integration become easier and tried to eliminate all forms of barriers to global trade (George, 2010).

The integration of MFA/ATC into single undertaking trade regime under GATT/ WTO is scheduled into four stages. The first stage took place from 1st January 1995- 31st December 1997, during this period $16 \%$ of T\&C products to be integrated with GATT rules. The second stage happened between 1st January 1998-31st December 2001, during this time $17 \%$ of products will be integrated, and the third stage from 1st January 2002 to 31st December 2004 will integrate $18 \%$ of T\&C products. Starts from 1st January 2005 the rest of total production (49\%) will automatically be integrated under GATT rules (Naumann, 2006). As we can see from the schedule above, the impact of quota imposing would be most affected in the latter stages, and of course after the post-quota era.

WTO got its mandate to regulate all forms of multilateral trading from 2001 Doha Round. The round itself has completed the unfinished 199 Seattle Round (Stiglitz \& Charlton, 2005). Doha Round also knew as Development Round since they are trying to maximize growth and end poverty. Rodrik (2007) has argued on the alternative perspective of international trade regime for developing countries. WTO shall be seen as a part of theinstitutional integration, WTO has to bridge the gap between thepractical and strategic institution (Rodrik, 2007).

The Economic structure of a state is a complex system. There are too many dimensions that need to be comprehensively analyzed. The complexity of the structure is reflecting the competition between state and the market. In the broader context, regional economic cooperation becomes inevitable. The market already transformed as the primary institution of theworld economy (Gelinas, 2005). Expansion of the market was originally caused by a phenomenon called globalization, certain condition where borders of nations seem to be blurred. Globalization became a continuous process which placed men as the dominant power, gained access to resources, and be economically benefited (Peterson, 2005).

The market is one of the most importantdimensions in economics. The market can be defined as astructured connection which operated through the freedom of both parties, producer, and consumer. T\&C Industry offered such an opportunity to expand the market, especially for newly industrialized countries, like Indonesia and Bangladesh (Hermawan, 2011). Indonesia and Bangladesh are two emerging market; both are having competitive T\&C industries and become one of the biggestcontributors of Gross Domestic Product (GDP).

Indonesia and Bangladesh are two major exporting countries in T\&C. As the newly industrialized countries, $\mathrm{T} \& \mathrm{C}$ has played apivotal role in their emerging market. Bangladesh for instance, according to the data provided by Bangladesh Investment Development Authority (BIDA) T\&C has the biggest share in country's GDP, as high as US $\$ 16$ billion or $77 \%$ of their total export in 2009-2010. Meanwhile, Indonesia successfully gained US $\$ 11,2$ billion from T\&C during the same period. By the time being, those numbers are getting higher.

Randriamaro (2003) argued that gender has become the key factor to see the relations between trade, growth, and development. However, trade policies are often assumed as gender-neutral. The state should recognize the economic contribution of women, both in productive labor, and unpaid female reproductive work. Trade policies have different impacts on women and men; this is due to gender inequality, unequal access between women and men in the policy-making process, including the economic sector.

The impact is also caused by the gendered work separation. Trade liberalization offers theopportunity to increase the number of women in labor force, especially in the export-based industries such as T\&C. Why is it so? Women workers are always presumed as low-skilled labors; it suited them. Since they have lower education rate compared to men workers. As the consequences, women are only gained 
theinsignificant amount of wages. This made the gender gap has become wider, men are maintained their position as breadwinner, and then women are still classified as secondary income (Rice, 2010).

Gender inequality and trade should be perceived as an interaction between those two factors. Trade reform through liberalization will make a different impact on women (genderdifferentiated) since both parties had different access and limited control of resources, they also had adifferent role in daily economic activities. Gender inequality has limited women to gain more benefit from trade liberalization.

Trade liberalization has restructured the economy, changed labor market, and in the extreme form, it can lead to unemployment. Market openness will require abusiness to perform efficiencies, and women are often become avictim, due to their limited skills (Randriamaro, 2003).

Many international agreements had not given any sufficient scope for gender consideration. It is very often that the agreement did not have any specific articles related to gender. This is the part when discrimination is started.Randriamaro (2003) stated that the participations of women and gender experts in the formulation of trade liberalization policies are important. Including in the process of negotiation. Women should be encouraged to be involved in the whole process at all levels, in doing so the policies formed have a gender perspective.

The impact of international trade can be seen through to what extent the obstacles havebeen overcome. The development of technology has caused transportation and communication factor is no longer consideredas asignificant obstacle. As for now, the biggest comes from the policies taken by the government, which provides tariffs barriers.

The Heckscher-Ohlin theorem is one of the references in international trade. The main argument of the theory that when a country's domestic market becomes open to international trade, the country will start to export goods and services, which they have acomparative advantage in theproduction process. Comparative advantage refers to the availability of factors of production on a large scale so that the State can use it at a cheaper cost. In a liberalized market, this comparative advantage can produce cheaper goods and services for a wider market. On the other hand, goods and services that require ahigher cost to produce will be imported from economically-stable countries (Rivera-Batiz, 2013).

Textiles and Clothing industries havebeen characterized by low wages and bad working environment. Trade liberalization is aimed to reach the maximum capacity of those resources. In the global industrialized society, trade liberalization has created the now labor force due to the investment. However, at the same time, the businessis still had to follow the rule of efficiency.

Those conditions above havebeen formulated as follows: How the two countries deliver their policy responses to overcome the impact of trade liberalization in textiles and clothing on women workers between 2010-2015?

\section{OVERVIEW ON INDONESIA AND BANGLADESH T\&C INDUSTRIES}

Indonesia is ranked as the fourth most populous country with nearly 240 million of its inhabitants. Indonesia is also become one of the biggest economic power, alongside with the other G20 members. The dynamics of theT\&C industry in Indonesia cannot be separated from the changing in global economy structure, including the Asia Financial Crisis in the late 1990s. The Crisis affected national economy most destructively. Unemployment has become inevitable, as well as the lowering of thewage rate, and worsened working environment (Robertson, Sitalaksmi, Ismalina, \& Fitrady, 2009).

T\&C industries have been around for years, even during the Dutch Colonization (Hill, 1997). It continued to growth under New Order regime, before the adjustmentcomesinto effect in the mid1980s. T\&C industries are divided into three subsectors: spinning and syntheticfiber, weaving and fabric production, and garment (readymade). Spinning and Synthetic Fibre has slightly different characteristic compared to the other two; theytend to be more capital intensive rather than labor intensive (Yastuti, 2004).

There are several milestones that we need to know to understand the rise of T\&C industry in Indonesia. The structural adjustment that took place in 1970-1980 in manufacturing, agriculture, and services has set as the important stage. Before the adjustment happened, Indonesia's economy is relied on oil and gas industry, when the price of oil and gas was weakened in the mid1980s, it has damaged the economy. Economic 
growth has fallen into only $3,7 \%$. It was a very significant changed compared to 7,5\% growth in 1975-1980 (Basri \& Soesastro, 2005). The government responded quickly to tackle those issues, one of the notable policy was outwardlooking trading policy. The primary priority is set to gain more investment in non-traditional sectors, besides oil and gas (Basri \& Soesastro, 2005).

The outward-looking policy has changed the structure of thenational economy. Before the policy was implemented, trade is heavily protected, and when the policy has been made the paradigm has shifted from import substitution industry to exporting manufacture products. Indonesia also went through financial deregulation, which invested became easier.

Robetson, Sitalaksmi, Ismalina, \& Fitrady (2009) has classified those changes into four waves, as follows: (1) The First Wave 1980-1990, during this time the Government tried to diversified the economy, with focus on three aspects: trade liberalization, investment reform, and changing industrial policy. (2) The Second Wave 1994-1995, during this phase Indonesia has become the biggest 12 countries in securing foreign direct investment. T\&C industries are one of the popular, with chemical and metal manufactures. (3) The Third Wave 1997-1999, the crisis happened, followed by capital flow, which hasstruck badly. (4) The Fourth Wave 2000-2006, this phase could be remembered as economic recovery. T\&C industries affected quite bad, yet they reclaimed their position as popular investment sectors.

The numbers of women workers in were getting higher by the time being. As Blackburn (2004) mentioned from 1971-1995, there was a significant growth from $37 \%$ to $47 \%$. Those numbers indicated that even during the repressive regime, women had influenced the economic development and the economic growth. Women workers are still the backbone, during 2008-2010 around 78\% of their workers are women, and nearly $80 \%$ are young women from 21-35 years old (Utomo, 2013).

On the other hand, Bangladesh is ranked as the eighth most populous countries with 156 millioninhabitants. The capital Dhaka also has the highest density in population, around 18 million (Khan, 2015). Political instability during the independence from Pakistan has pushed them to take several policies, one of those was Golden Bangladesh. It served as the main principle towards industrialization period. Shortly after independence, all of theeconomic sectors were managed by thestate through economic nationalization programs. This condition was merely for a short period before the government agreed to implement more outward-looking economic policy. Therefore the private sectors are back in business (Hassan, 2008).

The development of T\&C industries has changed the urban and rural landscapes in Bangladesh. The opening of thenew industrial zone and the EPZs meant the opening of new labor forces. Urbanization became inevitable. As mentioned above, the new labor forces are predominantly women, comprised nearly $85 \%$ of total (Khan, 2015), they have left their villages then moved to Dhaka or Chittagong. This phenomenon has aunique social impact before the industrialization begin women are excluded from economic-sphere, they did not have any access to theformal economy. When the industries growth, they became the backbone (Lewis, 2011).

It took 15 years for Bangladesh to claim the 8th position of the biggest T\&C producer countries. Ahmed (2004) argued that it changed the economic structure, Bangladesh has transformed to proto-capitalist state. The structuraladjustment that happened during Golden Bangladesh era, relied on strategies such as: devaluation, tariff reduction, tax holiday, and expansion of EPZs.

Bangladesh is quite successfulin combiningindustrialization and poverty alleviation. Fukunishi \& Yamagata (2014) explained that T\&C industries hadprovided asignificant contribution to poverty alleviation, women empowerment, and economic growth.

\section{HOW ARE WOMEN AFFECTED BY TRADE LIBERALIZATION IN T\&C?}

The relation between feminism and international economy through international trade regime (WTO) has become one of theunderstudiedareas in feminism and politics. International trade regime can be seen as nongendered discourse. Feminist critique towards this argument stands on all the basic knowledge about production, and productive action has been identified as amale domain. While the reproductive and domestic work were always identified for female. Work cannot be understood without examining how gender is embedded in all social relations (Peterson, 2005). It has raised 
some concerns, what kind of theoretical framework we can use to analyze that kind of relation? How are women affected by trade liberalization?

Two main perspectives presented by Mengesha (2008) are: state-market dichotomy and the discriminatory nature of trade regime against third world states. It may also include that the incapacitate governments of poor states from benefiting from trade and further from meeting their obligations towards fulfilling the socioeconomic need of their citizens (Mengesha, 2008). She also indicates that the poor women located mostly in developing and less developed countries that shoulder the brunt of dislodging effects of trade liberalization. In the developed economies where liberalization has resulted in adverse impacts, it is in the majority of cases poor women concentrated in low paying jobs that are dislocated from their livelihood (Mengesha, 2008).

Feminists have shown that the construction of the market-state dichotomy is flawed and can be challenged as non-existing. The market is not a natural phenomenon but is rather a social construction. Global trade increased the vulnerability of women. In the face of such consequences, state intervention becomes crucial for dealing with inequalities (Mengesha, 2008).The marketis considered as apublic sphere where all of the resources are being held by men. Accordingly, women's role and experiences are being ignored. Without the state intervention in themarket economy, the redistribution of resources is not benefiting for women, since they are economically marginalized. In the global scale, trade liberalization increased the vulnerability of women. The stateshouldtake action. Why is it so? Using state-market logic, women's interest can be considered as underrepresented. Women did not have sufficient access and control to productive resources. Inequal gender relation resulting the doubleburden for women workers (Mengesha, 2008)

In the critique to single undertaking regime, it comprises into two separated groups: full rejection, and thepossibilityof reforming. The first groups appear to reject all trade reform since the underlying principles of the trade regime are inimical to the interest of women. As such, the argument is that while the system is operating on these fundamental bases, it will not be wise to expect positive outcomes in the interest of women from the regime (Mengesha, 2008).
Wedderburn \& Jackson (2008) tried to identify the gender implication from multilateral economic agreement called Economic Partnership Agreement (EPA) which bound European Union (EU) and Carribean Community (CARICOM) in 2008. In their research, Wedderburn and Jackson explained that there was a significant implication between trade openness (liberalization) with thefeminization of labors across sectors, as the specific outcomes of trade agreements impact women and men differently depending on their location in society and the economy. These differential impact on women and men are linked to socio-economic aspects of their livelihoods because women and men's economic performance is influenced by their gendered realities. Their capacity to benefit from any opportunities associated with trade liberalization requires analysis using gender lens, to identify how their experiences differ, and how their livelihoods affected (Wedderburn \& Jackson, 2008, p.128).

Overworked and underpaid are two main effects that women workers have suffered. Bangladesh, for instance, according to Bangladeshi law, workers are supposed to work on eight-hour shift. However, garment workers are forced to put extra hours on a daily basisto meet the unrealistic production target set by factory owners. (Alam \& Blanch, 2011). Alam and Blanch (2011) researched working condition in thegarment industry in Bangladesh; the result was harsh. The wages of $96 \%$ of the garment workers they interviewed are depended on meeting production targets. Extra hours worked to meet production target are not considered overtime. Therefore they are unpaid (Alam \& Blanch, 2011).

Employers claimed the production targets are achievable in aneight-hour shift, but $64 \%$ of women workers fail to meet their targets within theallocated time. One in three of those interviewed reported working an extra 11-20 hours per month to meet the target, and thereby guarantee the basic salary, while $23 \%$ work 21 30 hours extra (Alam \& Blanch, 2011). Workers are also put under particular pressure when the date for shipment of an order is close. To meet demanding shipment deadlines, workers are persuaded by management to work until midnight without a break.

Those terrible conditions are also happened in Indonesia, although in theslightly different environment. Unpaid overtime can be considered 
as the most common thing that ever happened in T\&C industries. Women workers had suffered from economic exploitation. According to Government Regulation No.78 Year 2015, women workers shall enjoy their reproductive rights, such as menstrual leave, and maternity leave. However, the rules are not yet implemented by the industries, in the name of productivity, workers' right isbeing neglected.

\section{POLICY RESPONSES FROM INDONESIA AND BANGLADESH: ADDRESSING THE IMPACT}

Industrialization and trade liberalization has raised the new class of women factory workers. The government of Indonesia and Bangladesh had tackled the economy with determination, assisted by foreign aid and investment. It had remarkable success in promoting economic stability and growth, yet in the process, it eliminated several workers' rights.

Minimum wage policy has become the determining factorto address the impact of liberalization. The minimum wage is an attractive policy tool for poverty reduction and improving social justice. It ita complex yet feasible way for the government to show their commitment to support those at the bottom of income distribution, requiring no significant direct government expenditures, and can easily be targeted to the working poor.

The minimum wage concept had been originated in New Zealand, followed by Australia in the late 19th Century in response to public demands for social justice among workers. Since that time, many other industrialized countries, as well as some developing countries had also carried out experiments with minimum wage regulations for the protections for the vulnerable workers(BILS, 2015). There is no universal definition of national minimum wage. It is usually considered as the most successful labor market intervention that improves the income of low earners. At first, ILO introduces the minimum wage regulation for ensuring workers' reasonable standard of life, yet none of its term defines it.

Bangladesh does not have a minimum wage act, but a Minimum Wage Board has been in existence since 2006 when the Labor Act was adopted. In 2013, Labor Act was succeeded by the Bangladesh Labor Amendment Act. The Minimum Wage Board determines the minimum wage. It it comprised of four members appointed by the government: a chairperson, employers representatives, workers' representatives, and an independent member. Minimum wages in Bangladesh must be increased at least every five years (Clean Clothes Campaign, 2017).

The point above is the majordifferent, while in Indonesia, the minimum wages are revised annually. There are several regulations on this issue: (1) Regulation of the Ministry of Manpower and Transmigration No. 7 Year 2013 concerning Minimum Wage; (2) Presidential Instruction No.9 Year 2013 on Minimum Wage Fixing Policy Framework for Improved Business Continuity and Workers Welfare; (3) Regulation of Ministry of Manpower and Transmigration No.13 Year 2012 on Decent Living Standards; (4) Government Regulation No.78 Year 2015 on Remuneration; (5) Gubernatorial Regulation in each provinces.

The minimum wage was increased around $15 \%$ in average annually, compared to Bangladesh which only increased $25 \%$ in five years period ( $5 \%$ p.a), even the number was seemingly high, the annual increase has not been keeping up with the annual inflation which ranges from $7-12 \%$ p.a. (Clean Clothes Campaign, 2017). Therefore, at this point, workers in Indonesia seemingly have afinancial safety. The Government of Bangladesh did not pay much attention to address the impact on this issues. It reflected on how they managed the minimum wage policy, which did not consider the annual inflation rate. The government is also reluctant to address the impact of economic exploitation on women workers.

Nevertheless, the increased wage could be a burden for labor-intensive industries, such as T\&C. Before the Government Regulation 78/2015 was adopted, the minimum wagewas determined under political pressure, which resulted in the weak rule of law and threatening business continuity. Indonesia also has National Wage Board, a tripartite non-structural institution which comprised of state, business, and workers. They also have independent members from universities and experts.

Workers Unions are constantly demand to revise the decent live standards which be used as the basic argumentation when formulating the minimum wage; they argued that those numbers not add up. The Decent Living Standard was standardized by the needs of a single worker. Some of the workers argued that discriminate them when they are already starting a new family. 
It also raised some critique from women workers union, which stated that their needs as women have not yet fulfilled by the rules in Government Regulation 78/2015.At first, the regulation was aimed to achieve the decent living for workers, including the women workers.There was animprovement, when we talked about the menstrual leave. Women workers are granted 2 days off when they need to take the menstrual leave, or they still granted three months for maternity leave. The rules are not enough; women workers are still facing discrimination. Mostwomen workers in T\&C did not get equal chance to prove their quality to be promoted tosupervisor because the company thinks that when women workers will stop working when they are getting married. So, the company thinks that there are no urges to improve their working conditions.

Contrary to the fact, Bangladesh Government is eagerly awaiting to increase the investment through the expansion of EPZs. There are currently 8 EPZs throughout the country: Adamjee, Chittagong, Comilla, Dhaka, Ishwardi, Karnaphuli, Mongla, and Uttara. The government provides various incentives for investors when they are agreed to open new factories in EPZs. The company will be granted5 years tax-free. Also, they will be safe from workers' union demand since the Union is banned inside the EPZs. Furthermore, the government of Bangladesh had already approved 37-new authorized economic zones all over the country.From this notion, we can conclude that the government of Bangladesh are likely to expand their production basis rather than empowering their workers.

The policy responses between Indonesia and Bangladesh relied on thevery basic question: Which side are youon? The Government of Indonesia are likely to choose the populist way, tried to get the workers attention by favoring their needs through Government Regulation $78 / 2015$, eventhough there is always a debate on whether those regulation arefavoring the workers or not. On the other side, the Government of Bangladesh is likely to side with the business. The expansion of EPZs with all of the incentives within implied that the government is still reluctant to empower their workers.Alas, thestate-business relation is getting more complicated from time to time.

\section{BIBLIOGRAPHY}

Ahmed, F. E. (2004). The Rise of the Bangladesh Garment Industry: Globalization, Women Workers, and Voice. NSWA Journal, 3455.

Alam, K., \& Blanch, L. (2011). Stitched Up: Women Workers in the Bangladeshi Garment Sector. London: War on Want.

Basri, M. C., \& Soesastro, H. (2005). The Political Economy of Trade Policy in Indonesia. CSIS: Economics Working Paper Series, 129.

BILS. (2015). National Minimum Wage for Bangladesh's Workers: Rational Standard and Rationality of National Minimum. Dhaka: Bangladesh Institute of Labor Studies.

Blackburn, S. (2004). Women and State in Modern Indonesia. Cambridge: Cambridge University Press.

Clean Clothes Campaign. (2017). Wage Struggle in Bangladesh. Dhaka: Clean Clothes Campaign.

Fukunishi, T., \& Yamagata, T. (2014). The Garment Industry in Low-income Countries: An Entry Point of Industrialization. UK: Palgrave Macmillan.

Gelinas, J. B. (2005). Juggernaut Politics: Understanding Predatory Globalisation. New York: Zed Books.

George, C. (2010). The Truth About Trade: The Real Impact of Liberalization. London: Zed Books.

Hale, A. (2002, February). Trade Liberalisation in The Garment Industry: Who Is Really Benefitting? Development in Practice, 12(1), 33.

Hermawan, I. (2011). Analisis Dampak Kebijakan Makroekonomi Terhadap Perkembangan Industri Tekstil dan Produk Tekstil Indonesia. Buletin Ekonomi Moneter dan Perbankan, 374.

Heron, T. (2012). The Global Political Economy of Trade Protectionism and Liberalization: Trade Reform and Economic Adjustment in Textiles and Clothing. London: Routledge.

Hill, H. (1997). Indonesia's Industrial Transformation. Singapore: ISEAS.

Khan, A. R. (2015). The Economy of Bangladesh: A Quarter Century of Development. London: Palgrave Macmillan.

Mengesha, E. (2008). Rethinking the Rules and Principles of The International Trade 
Regime: Feminist Perspectives.Agenda: Empowering Women for Gender Equity, 13-26.

Naumann, E. (2006). The Multifibre Agreement WTO Agreement on Textiles and Clothing. TRALAC.

Peterson, V. S. (2005). How (The Meaning of) Gender Matters in Political Economy. New Political Economy.

Rice, J. S. (2010). Free Trade, Fair Trade, Gender Inequality in Less Developed Countries. Sustainable Development Journals.

Rodrik, D. (2007). One Economics, Many Recipes: Globalization, Institutions, and Economic Growth. New Jersey: Princeton University Press.

Sally, R., Alves, P., \& Draper, P. (2009). The Political Economy of Trade Reform in Emerging Markets: Crisis or Opportunity? United Kingdom: Edward Elgar Publishing Ltd.

Septi, D. (2016, Maret 3). Buruh Perempuan dan Kawasan Industri Rumah Pabrik dan Serikat Buruh. Dipetik November 11, 2016, dari Majalah Sedane: http://majalahsedane.org

Sudrajat, U. A. (2008). Country Reports on Coping with Restrictive Policies and Maintaining Competitiveness: Indonesia. Dalam E. a. (ESCAP), Unveiling Protectionism: Regional Responses to
Remaining Barriers in the Textiles and Clothing Trade (hal. 204-2013). Thailand: United Nations.

Underhill, G. R. (1998). Industrial Crisis and the Open Economy: Politics, Global Trade, and the Textile Industry in the Advanced Economies. London: Macmillan.

Utomo, H. K. (2013). Dampak Liberalisasi Industri Tekstil Terhadap Kesejahteraan Perempuan Buruh di Industri Tekstil Nasional Pada Masa Pemerintahan Suharto dan Susilo Bambang Yudhoyono, 62. Depok, Indonesia.

Wedderburn, J., \& Jackson, J. (2008). Gender and the Economic Partnership Agreement: An Analysis of the Potential Gender Effects of the CARIFORUM-EU. Carribean Development Report.

Yastuti, T. I. (2004). Dampak Penghapusan Kebijakan Kuota MFA (Multi-Fibre Arrangement) terhadap Daya Saing dan Pemasaran Sektor Tekstil dan Produk Tekstil. Skripsi. Bogor: Institut Pertanian Bogor.

Yunus, M., \& Yamagata, T. (2014). Bangladesh: Market Force Supersedes Control. Dalam T. Fukunishi, \& T. Yamagata, The Garment Industry in Low-Income Countries: An Entry Point of Industrialization (hal. 77103). Hampshire: Palgrave Macmillan. 